\title{
PENGARUH PEMBERIAN PAKAN ALAMI DAN PAKAN BUATAN TERHADAP PERTUMBUHAN BENIH IKAN BETUTU (Oxyeleotris marmorata Bleeker)
}

\section{THE INFLUENCE OF GIVING NATURAL FEED AND MAKE FEED TO GROWTH FINGERLINGS OF BETUTU (Oxyeleotris marmorata Bleeker)}

\author{
Muhammad Arief ${ }^{1}$, Irmaya Triasih ${ }^{1}$ dan Widya Paramita Lokapirnasari ${ }^{2}$ \\ ${ }^{1}$ Fakultas Perikanan dan Kelautan Universitas Airlangga \\ Kampus C Mulyorejo - Surabaya 60115 Telp. 031-5911451 \\ ${ }^{2}$ Fakultas Kedokteran Hewan Universitas Airlangga \\ Kampus C Mulyorejo - Surabaya 60115 Telp. 031-5993016
}

\begin{abstract}
The growth of betutu classified slow, so do efforts in order that growth of betutu which protected optimal by choosing the exact food combination. This research is purpose to know the growth fingerlings of betutu. This research using complete random program giving 3 repeated by the way of treating P1 (food 100\% pelet), P2 (food 100\% Daphnia spp.), P3 (food 100\% Tubifex sp.), P4 (food 100\% Anadara granosa), P5 (food combination 50\% pelet and 50\% Daphnia spp.), P6 (food combination 50\% pelet and $50 \%$ Tubifex sp.), P7 (food combination 50\% Anadara granosa and 50\% Daphnia spp.), P8 (food combination 50\% Anadara granosa and 50\% Tubifex sp.). Main test parameter checked on this research is growth (accretion weight), growth rate, specific growth rate, and absolute body length growth, while supporting test parameter is water quality. Data of growth analysis using ANAVA (varian analysis) and if there is the influence the way of treating so continued with Test of Multiple Gap Duncan by trusty degree $95 \%$. The result of research show the growth (accretion weight), growth rate, specific growth rate and the best absolute body length growth on the way of treating P6 which not different with the way of treating P3 and P8.
\end{abstract}

Key words : growth (accretion weight), growth rate, specific growth rate, absolute body length growth.

\section{Pendahuluan}

Ikan betutu (Oxyeleotris marmorata Bleeker) merupakan ikan konsumsi yang menjadi salah satu komoditas perikanan air tawar yang mulai dikenal pada awal tahun 1987. Ikan ini mempunyai potensi besar untuk dibudidayakan (Lingga, 1987 dalam Palupi, 1990). Daging ikan betutu yang rata-rata mengandung protein $(9-22 \%)$, lemak $(0,1-$ $20 \%)$, mineral $(1-3 \%)$, vitamin, lecithin, guanin dan sedikit mengandung kolesterol (Mulyono, 2001).

Ikan betutu selama ini lebih banyak diambil dari alam dan jarang sekali dibudidayakan. Kendala yang ditemui adalah pertumbuhan ikan betutu yang lambat. Induk ikan betutu akan memijah pada saat musim penghujan saja sehingga mengalami keterbatasan benih untuk dibudidayakan secara berkelanjutan (Komarudin, 2000).

Pertumbuhan dipengaruhi oleh faktor internal antara lain genetik, aktifitas, spesies, jenis kelamin, umur dan ukuran ikan, kondisi fisiologi; sedangkan faktor eksternal berkaitan dengan lingkungan tempat hidup ikan (Mukti dkk, 2003). Pertumbuhan ikan betutu tergolong lambat, sehingga dilakukan upaya agar pertumbuhan ikan betutu yang dipelihara dapat optimal yaitu dengan pemilihan kombinasi pakan yang tepat.

Pakan merupakan faktor yang memegang peranan sangat penting dan menentukan dalam keberhasilan usaha perikanan dan ketersediaan pakan merupakan salah satu faktor utama untuk menghasilkan produksi maksimal (Darmawiyanti, 2005). Syarat pakan yang baik adalah mempunyai nilai gizi yang tinggi, mudah diperoleh, mudah diolah, mudah dicerna, harga relatif murah, tidak mengandung racun. Jenis pakan disesuaikan dengan bukaan mulut ikan, dimana semakin kecil bukaan mulut ikan maka semakin kecil ukuran pakan yang diberikan, dan juga disesuaikan dengan umur ikan (Khairuman, 2003).

Tujuan dari penelitian ini adalah untuk mengetahui pengaruh pemberian pakan alami dan pakan buatan yaitu kerang darah (Anadara granosa), cacing tubifex (Tubifex sp.), kutu air (Daphnia spp.) dan pelet serta 
kombinasi pakan pelet dan kutu air, pelet dan cacing tubifex, kerang darah dan kutu air, kerang darah dan cacing tubifex terhadap pertumbuhan benih ikan betutu (Oxyeleotris marmorata Bleeker). Untuk mengetahui jenis pakan manakah yang memberikan pertumbuhan optimal benih ikan betutu (Oxyeleotris marmorata Bleeker).

Sedangkan manfaat yang diharapkan yaitu memberikan informasi ilmiah bagi ilmuwan, mahasiswa dan para pembudidaya mengenai budidaya benih ikan betutu, tentang penggunaan pakan alami dan pakan buatan yaitu kerang darah (Anadara granosa), cacing tubifex (Tubifex sp.), kutu air (Daphnia spp.) dan pelet serta kombinasi pakan pelet dan kutu air, pelet dan cacing tubifex, kerang darah dan kutu air, kerang darah dan cacing tubifex terhadap pertumbuhan benih ikan betutu (Oxyeleotris marmorata Bleeker). Memberikan informasi ilmiah tentang penggunaan pakan alami dan pakan buatan yang baik terhadap pertumbuhan optimal benih ikan betutu (Oxyeleotris marmorata Bleeker).

\section{Materi dan Metode Penelitian}

Penelitian ini dilaksanakan pada bulan 10 November 2007 sampai 06 Januari 2008 di Laboratorium Pendidikan Perikanan Fakultas Kedokteran Hewan, Universitas Airlangga. Analisis proksimat dilakukan di Laboratorium Pakan Ternak Fakultas Kedokteran Hewan, Universitas Airlangga.

Alat yang digunakan dalam penelitian adalah bak plastik sebanyak 24 buah dengan volume 5 liter, waring, aerator dan selang aerator, timbangan digital dan penggaris. Pengukuran kualitas air digunakan kertas $\mathrm{pH}$ universal, termometer, amonia test dan $\mathrm{O}_{2}$ test.

Benih ikan betutu dengan panjang tubuh $1 \mathrm{~cm}$ dan berat $0,1 \mathrm{~g}$ berasal dari pembudidaya di Yogyakarta, pakan ikan yaitu pelet, kutu air (Daphnia spp.), cacing tubifex (Tubifex sp.) dan kerang darah (Anadara granosa).

Penelitian ini menggunakan Rancangan Acak Lengkap (RAL) dengan 8 perlakuan dan 3 ulangan. Perlakuan tersebut yaitu :

P1 : Pakan $100 \%$ pelet

P2 : Pakan 100\% kutu air (Daphnia spp.)

P3 : Pakan $100 \%$ cacing tubifex (Tubifex sp.)

P4 : Pakan 100\% kerang darah (Anadara granosa)

P5 : Pakan kombinasi 50\% pelet dan 50\% kutu air (Daphnia spp.)

P6 : Pakan kombinasi 50\% pelet dan 50\% cacing tubifex (Tubifex sp.)
P7 : Pakan kombinasi 50\% kerang darah (Anadara granosa) dan 50\% kutu air (Daphnia spp.)

P8 : Pakan kombinasi 50\% kerang darah (Anadara granosa) dan 50\% cacing tubifex (Tubifex sp.)

Parameter uji utama pada penelitian ini adalah pertumbuhan (pertambahan berat) benih ikan betutu.

Pertumbuhan (Growth)

(G) $=\mathrm{Wt}-\mathrm{Wo}_{0}$

Keterangan :

$\mathrm{G}=$ Pertumbuhan $(\mathrm{g})$

$\mathrm{Wt}=$ Berat rata-rata akhir $(\mathrm{g})$

Wo = Berat rata rata awal $(\mathrm{g})$

Sumber : Hariati (1989)

Laju Pertumbuhan (Growth Rate)

$$
(\mathrm{GR})=\frac{\mathbf{W t}-\mathbf{W o}}{\mathbf{t}}
$$

Keterangan :

GR = Laju pertumbuhan (g/hari)

$\mathrm{Wt}=$ Berat rata-rata akhir $(\mathrm{g})$

Wo $=$ Berat rata rata awal $(\mathrm{g})$

$\mathrm{t} \quad=$ waktu (hari)

Sumber : Elliott and Hurley (1995)

Laju Pertumbuhan Spesifik (Spesific Growth Rate)

$$
(\mathrm{SGR})=\frac{(\ln \mathrm{Wt}-\ln \mathrm{Wo})}{t} \times 100 \%
$$

Keterangan :

$\mathrm{SGR}=$ persentase berat rata-rata individu per hari (\% Berat tubuh/hari)

$\mathrm{Wt}=$ berat rata rata pada waktu ke-t $(\mathrm{g})$

$\mathrm{Wo}=$ berat rata-rata awal $(\mathrm{g})$

$\mathrm{t}=$ waktu (hari)

Sumber : Elliott and Hurley (1995)

Panjang Tubuh Mutlak

Pertumbuhan panjang tubuh mutlak benih ikan betutu dapat dihitung dengan menggunakan rumus yang dikemukakan Effendie (1997), sebagai berikut :

Pertumbuhan panjang mutlak $=\mathrm{T} \mathrm{L}_{1}-\mathrm{T} \mathrm{L}_{0}$

Keterangan :

$\mathrm{TL}_{1}=$ panjang total pada akhir pemeliharaan (mm)

$\mathrm{TL}_{0}=$ panjang total pada awal pemeliharaan ( $\mathrm{mm})$

Sumber : Hariati (1989)

Parameter uji penunjang pada penelitian ini adalah kualitas air yaitu : suhu, $\mathrm{pH}$, oksigen terlarut dan amoniak.

Hasil penelitian ini kemudian akan 
dianalisis menggunakan analisis varian (Anova) untuk mengetahui nilai keragaman dan untuk mengetahui perlakuan mana yang berbeda diantara semua perlakuan maka dilakukan Uji Jarak Berganda Duncan untuk mengetahui perlakuan yang terbaik dengan derajat kepercayaan 95\% (Kusriningrum, 2008).

\section{Hasil dan Pembahasan}

Pertumbuhan

Benih ikan betutu (Oxyeleotris marmorata) yang diberi berbagai jenis pakan yaitu pelet, kutu air (Daphnia spp.), cacing tubifex (Tubifex sp.), kerang darah (Anadara granosa). Pertumbuhan berat tubuh selama 2 bulan penelitian dapat dilihat pada Tabel 1 .

Berdasarkan analisis statistik dengan menggunakan Anova menunjukkan adanya pengaruh nyata dari pemberian pakan alami dan pakan buatan terhadap pertumbuhan berat benih ikan betutu (Oxyeletris marmorata) $(\mathrm{p}<0,05)$.
Sedangkan berdasarkan hasil Uji Jarak Berganda Duncan menunjukkan bahwa pertambahan berat pada perlakuan P6 $(50 \%$ pelet dan $50 \%$ cacing tubifex) tidak berbeda nyata $(p>0,05)$ dengan perlakuan P3 $(100 \%$ cacing tubifex) dan P8 (50\% kerang darah dan $50 \%$ cacing tubifex. Perlakuan P3 dan P8 tidak berbeda nyata $(\mathrm{p}>0,05)$ dengan perlakuan $\mathrm{P} 4$ (100\% kerang darah), P5 (50\% pelet dan 50\% Daphnia spp.), dan P7 (50\% kerang darah dan 50\% Daphnia spp.). Perlakuan P7 tidak berbeda nyata ( $\mathrm{p}>0,05)$ dengan perlakuan P3, P4, P5 dan P2 (100\% Daphnia spp.). Perlakuan P1 (100\% pelet) dengan rata-rata pertumbuhan berat tubuh yang terendah berbeda nyata $(\mathrm{p}<0,05)$ dengan semua perlakuan.

Rata-rata Laju Pertumbuhan dan Laju Pertumbuhan Spesifik

Rata-rata laju pertumbuhan (Growth Rate) benih ikan betutu pada perlakuan berbagai

Tabel 1. Rata-rata pertumbuhan berat tubuh benih ikan betutu selama penelitian $(\mathrm{g})$

\begin{tabular}{|ll|rc|}
\hline \multicolumn{1}{|c|}{ Perlakuan } & \multicolumn{2}{c|}{ Rata-rata \pm SD } \\
\hline P1 & 100\% Pelet & $0.2700^{\mathrm{d}} \quad \pm 0.02000$ \\
\hline P2 & 100\% Kutu air (Daphnia spp.) & $0.3067^{\mathrm{c}}$ & \pm 0.01528 \\
\hline P3 & 100\% Cacing tubifex (Tubifex sp.) & $0.5567^{\mathrm{ab}}$ & \pm 0.01155 \\
\hline P4 & 100\% Kerang darah (Anadara granosa) & $0.3800^{\mathrm{b}}$ & \pm 0.02000 \\
\hline P5 & $\begin{array}{l}\text { Kombinasi 50\% Pelet dan 50\% Kutu air (Daphnia } \\
\text { spp.) }\end{array}$ & $0.3867^{\mathrm{b}}$ & \pm 0.01528 \\
\hline P6 & $\begin{array}{l}\text { Kombinasi 50\% Pelet dan 50\% Cacing tubifex } \\
\text { (Tubifex sp.) }\end{array}$ & $0.5767^{\mathrm{a}}$ & \pm 0.00577 \\
\hline P7 & $\begin{array}{l}\text { Kombinasi 50\% Kerang darah (Anadara granosa) } \\
\text { dan 50\% Kutu air (Daphnia } \text { spp.) }\end{array}$ & $0.3700^{\mathrm{bc}} \pm 0.02000$ \\
\hline P8 & $\begin{array}{l}\text { Kombinasi 50\% Kerang darah (Anadara granosa) } \\
\text { dan 50\% Cacing tubifex (Tubifex sp.) }\end{array}$ & $0.5533^{\mathrm{ab}}$ & \pm 0.00577 \\
\hline
\end{tabular}

Keterangan : Superskrip yang berbeda pada kolom yang sama menyatakan bahwa terdapat perbedaan $(\mathrm{p}<0,05)$

Tabel 2. Rata-rata laju pertumbuhan (growth rate) (g/hari)

\begin{tabular}{|c|c|c|c|}
\hline \multirow{2}{*}{\multicolumn{2}{|c|}{ Perlakuan }} & \multicolumn{2}{|c|}{ Growth Rate } \\
\hline & & \multicolumn{2}{|c|}{ Rata-rata \pm SD } \\
\hline & $100 \%$ Pelet & $0.002867^{\mathrm{d}}$ & \pm 0.003512 \\
\hline $\mathrm{P} 2$ & $100 \%$ Kutu air (Daphnia spp.) & $0.003467^{\mathrm{c}}$ & \pm 0.0002309 \\
\hline P3 & $100 \%$ Cacing tubifex (Tubifex sp.) & $0.007867^{\mathrm{ab}}$ & \pm 0.0001528 \\
\hline $\mathrm{P} 4$ & $100 \%$ Kerang darah (Anadara granosa) & $0.004767^{\mathrm{b}}$ & \pm 0.0003786 \\
\hline P5 & $\begin{array}{l}\text { Kombinasi } 50 \% \text { Pelet dan 50\% Kutu air (Daphnia } \\
\text { spp.) }\end{array}$ & $0.004933^{\mathrm{b}}$ & \pm 0.0003055 \\
\hline P6 & $\begin{array}{l}\text { Kombinasi } 50 \% \text { Pelet dan } 50 \% \text { Cacing tubifex } \\
\text { (Tubifex sp.) }\end{array}$ & $0.008200^{\mathrm{a}}$ & \pm 0.0000000 \\
\hline P7 & $\begin{array}{l}\text { Kombinasi } 50 \% \text { Kerang darah (Anadara granosa) } \\
\text { dan 50\% Kutu air (Daphnia spp.) }\end{array}$ & $0.004600^{\mathrm{bc}}$ & \pm 0.0003606 \\
\hline P8 & $\begin{array}{l}\text { Kombinasi } 50 \% \text { Kerang darah (Anadara granosa) } \\
\text { dan 50\% Cacing tubifex (Tubifex sp.) }\end{array}$ & $0.007933^{\mathrm{a}}$ & \pm 0.0000577 \\
\hline
\end{tabular}

Keterangan : Superskrip yang berbeda pada kolom yang sama menyatakan bahwa terdapat perbedaan $(\mathrm{p}<0,05)$ 
Tabel 3. Rata-rata laju pertumbuhan spesifik (Specific Growth Rate) benih ikan betutu selama penelitian (\% Berat tubuh/hari)

\begin{tabular}{|c|c|c|c|}
\hline \multirow{2}{*}{\multicolumn{2}{|c|}{ Perlakuan }} & \multirow{2}{*}{\multicolumn{2}{|c|}{$\begin{array}{c}\text { Spesific Growth Rate } \\
\text { Rata-rata } \pm \text { SD }\end{array}$}} \\
\hline & & & \\
\hline & $100 \%$ Pelet & $1.60000^{\mathrm{d}}$ & \pm 0.132525 \\
\hline $\mathrm{P} 2$ & 100\% Kutu air (Daphnia spp.) & $1.77733^{\mathrm{c}}$ & \pm 0.063721 \\
\hline P3 & 100\% Cacing tubifex (Tubifex sp.) & $2.79167^{\mathrm{ab}}$ & \pm 0.077951 \\
\hline $\mathrm{P} 4$ & $100 \%$ Kerang darah (Anadara granosa) & $2.16000^{\mathrm{b}}$ & \pm 0.128992 \\
\hline P5 & $\begin{array}{l}\text { Kombinasi } 50 \% \text { Pelet dan } 50 \% \text { Kutu air (Daphnia } \\
\text { spp.) }\end{array}$ & $2.16000^{\mathrm{b}}$ & \pm 0.070925 \\
\hline P6 & $\begin{array}{l}\text { Kombinasi } 50 \% \text { Pelet dan 50\% Cacing tubifex } \\
\text { (Tubifex sp.) }\end{array}$ & $2.88467^{\mathrm{a}}$ & \pm 0.018475 \\
\hline P7 & $\begin{array}{l}\text { Kombinasi 50\% Kerang darah (Anadara granosa) } \\
\text { dan 50\% Kutu air (Daphnia spp.) }\end{array}$ & $2.11267^{\mathrm{bc}}$ & \pm 0.130631 \\
\hline P8 & $\begin{array}{l}\text { Kombinasi } 50 \% \text { Kerang darah (Anadara granosa) } \\
\text { dan 50\% Cacing tubifex (Tubifex sp.) }\end{array}$ & $2.85467^{\mathrm{a}}$ & \pm 0.072169 \\
\hline
\end{tabular}

Keterangan : Superskrip yang berbeda pada kolom yang sama menyatakan bahwa terdapat perbedaan $(\mathrm{p}<0,05)$

Tabel 4. Rata-rata panjang tubuh mutlak benih ikan betutu selama penelitian (mm)

\begin{tabular}{|c|c|c|}
\hline & Perlakuan & Rata-rata \pm SD \\
\hline & $100 \%$ Pelet & $0.2200^{\mathrm{d}} \pm 0.1000$ \\
\hline $\mathrm{P} 2$ & 100\% Kutu air (Daphnia spp.) & $0.2433^{\mathrm{c}} \pm 0.1155$ \\
\hline P3 & $100 \%$ Cacing tubifex (Tubifex sp.) & $0.3333^{\mathrm{a}} \pm 0.0577$ \\
\hline P4 & $100 \%$ Kerang darah (Anadara granosa) & $0.2733^{\mathrm{b}} \pm 0.1528$ \\
\hline P5 & Kombinasi 50\% Pelet dan 50\% Kutu air (Daphnia spp.) & $0.2733^{\mathrm{b}} \pm 0.1528$ \\
\hline P6 & Kombinasi $50 \%$ Pelet dan $50 \%$ Cacing tubifex (Tubifex sp.) & $0.3433^{\mathrm{a}} \pm 0.0577$ \\
\hline P7 & $\begin{array}{l}\text { Kombinasi 50\% Kerang darah (Anadara granosa) dan } 50 \% \\
\text { Kutu air (Daphnia spp.) }\end{array}$ & $0.2633^{\mathrm{bc}} \pm 0.1528$ \\
\hline P8 & $\begin{array}{l}\text { Kombinasi 50\% Kerang darah (Anadara granosa) dan } 50 \% \\
\text { Cacing tubifex (Tubifex sp.) }\end{array}$ & $0.3333^{\mathrm{a}} \pm 0.0577$ \\
\hline
\end{tabular}

Keterangan : Superskrip yang berbeda pada kolom yang sama menyatakan bahwa terdapat perbedaan $(\mathrm{p}<0,05)$

jenis pakan terdapat pada Tabel 2.

Berdasarkan analisis statistik dengan menggunakan Anova menunjukkan bahwa adanya pengaruh nyata dari pemberian pakan alami dan pakan buatan terhadap rata-rata laju pertumbuhan (growth rate) benih ikan betutu (Oxyeletris marmorata) $(\mathrm{p}<0,05)$.

Berdasarkan hasil Uji Jarak Berganda Duncan menunjukkan bahwa rata-rata laju pertumbuhan terbaik terdapat pada perlakuan P6 (50\% pelet dan $50 \%$ cacing tubifex) tidak berbeda nyata $(\mathrm{p}>0,05)$ dengan perlakuan P8 (50\% kerang darah dan $50 \%$ cacing tubifex) dan perlakuan P3 (100\% cacing tubifex). Perlakuan P3 tidak berbeda nyata $(\mathrm{p}>0,05)$ dengan $\mathrm{P} 4$ (100\% kerang darah) dan P5 (50\% pelet dan 50\% Daphnia spp.). Perlakuan P4 dan P5 tidak berbeda nyata $(\mathrm{p}>0,05)$ dengan perlakuan P3 dan P7 (50\% kerang darah dan 50\% Daphnia spp.). Perlakuan P7 tidak berbeda nyata ( $>0,05)$ dengan perlakuan P3, P4, P5 dan P2 (100\% Daphnia spp.). Perlakuan P1 (100\% pelet) dengan rata-rata laju pertumbuhan yang terendah dan berbeda nyata $(\mathrm{p}<0,05)$ dengan semua perlakuan.

Rata-rata laju pertumbuhan spesifik (spesific growth rate) benih ikan betutu pada perlakuan berbagai jenis pakan terdapat pada Tabel 3.

Berdasarkan analisis statistik dengan menggunakan Anova menunjukkan adanya pengaruh nyata dari pemberian pakan alami dan pakan buatan memberikan terhadap rata-rata laju pertumbuhan spesifik (spesific growth rate) benih ikan betutu (Oxyeletris marmorata) $(\mathrm{p}<0,05)$.

Berdasarkan hasil Uji Jarak Berganda Duncan menunjukkan bahwa rata-rata laju pertumbuhan spesifik terbaik terdapat pada perlakuan P6 (50\% pelet dan 50\% cacing tubifex) tidak berbeda nyata $(\mathrm{p}>0,05)$ dengan perlakuan P8 (50\% kerang darah dan 50\% cacing tubifex) dan perlakuan P3 (100\% cacing tubifex). Perlakuan P3 tidak berbeda nyata ( $>0,05)$ dengan P4 (100\% kerang darah), P5 (50\% pelet dan 50\% Daphnia spp.) dan P6. 
Perlakuan P7 (50\% kerang darah dan 50\% Daphnia spp.) tidak berbeda nyata $(\mathrm{p}>0,05)$ dengan perlakuan P3, P4, P5 dan P2 (100\% Daphnia spp.). Perlakuan P1 (100\% pelet) dengan rata-rata laju pertumbuhan spesifik yang terendah berbeda nyata $(\mathrm{p}<0,05)$ dengan semua perlakuan.

Rata-rata panjang tubuh mutlak benih ikan betutu

Rata-rata panjang tubuh mutlak benih ikan betutu pada perlakuan berbagai jenis pakan terdapat pada Tabel 4. Berdasarkan analisis statistik dengan menggunakan Anova menunjukkan adanya pengaruh nyata dari pemberian pakan alami dan pakan buatan memberikan terhadap panjang tubuh mutlak benih ikan betutu (Oxyeleotris marmorata) $(\mathrm{p}<0,05)$. Berdasarkan hasil Uji Jarak Berganda Duncan menunjukkan bahwa pemberian pakan pada perlakuan P6 $(50 \%$ pelet dan $50 \%$ cacing tubifex), P3 (100\% cacing tubifex), dan P8 (50\% kerang darah dan 50\% cacing tubifex) berpengaruh nyata $(\mathrm{p}<0,05)$ terhadap panjang tubuh mutlak. Perlakuan P4 $(100 \%$ kerang darah) dan P5 (50\% pelet dan $50 \%$ kutu air) tidak berbeda nyata $(\mathrm{p}>0,05)$ dengan perlakuan P7 (50\% kerang darah dan 50\% kutu air). Perlakuan P7 tidak berbeda nyata $(\mathrm{p}>0,05)$ dengan perlakuan P2. Perlakuan P2 (100\% kutu air) berbeda nyata $(\mathrm{p}<0,05)$ dengan perlakuan P1. Perlakuan P1 (100\% pelet) dengan rata-rata pertumbuhan panjang tubuh mutlak yang terendah dan berbeda nyata $(\mathrm{p}<0,05)$ dengan semua perlakuan.

Pada penelitian ini parameter utama yang diukur adalah pertumbuhan (pertambahan berat), laju pertumbuhan, laju pertumbuhan spesifik, dan pertumbuhan panjang tubuh mutlak.

Hasil dari penelitian ini menunjukkan bahwa pemberian pakan alami dan pakan buatan berpengaruh nyata $(\mathrm{p}<0,05)$ terhadap pertumbuhan (pertambahan berat), laju pertumbuhan, laju pertumbuhan spesifik, pertumbuhan panjang tubuh mutlak benih ikan betutu. Pada perlakuan P6 (kombinasi pelet dan cacing tubifex) memberikan pengaruh yang lebih baik pada pertumbuhan, laju pertumbuhan, laju pertumbuhan spesifik dan pertumbuhan panjang tubuh mutlak benih ikan betutu dibanding perlakuan lain tetapi tidak berbeda nyata $(p>0,05)$ dengan pertumbuhan pada perlakuan P3 (cacing tubifex) dan P8 (kombinasi kerang darah dan cacing tubifex). Ketiga perlakuan tersebut ( P6, P3, P8) samasama menggunakan pakan alami berupa cacing tubifex yang banyak digunakan untuk pakan benih ikan betutu. Cacing tubifex memiliki kandungan protein sebanyak 48,53\%, lemak sebanyak $22,38 \%$, serat sebanyak $0,78 \%$, karbohidrat sebanyak $7,9678 \%$ dan memiliki energi akhir sebesar $706,74 \% \mathrm{kcal} / \mathrm{g}$. Menurut Khairuman (2005) dan Mudjiman (2000) bahwa kandungan protein pakan untuk sebagian besar ikan sebanyak 20-36\% dari berat pakan, kandungan lemak sebanyak $4-18 \%$ dari berat pakan. Berdasarkan hal tersebut diatas cacing tubifex mengandung nilai nutrisi yang sesuai untuk benih ikan betutu. Cacing tubifex juga mempunyai kelebihan yaitu mudah ditangkap oleh benih ikan betutu. Benih ikan betutu bersifat karnivora sehingga membutuhkan kandungan protein yang tinggi untuk pembentukan jaringan organ tubuh, dan perbaikan sel. Ikan karnivora mendapatkan karbohidrat dari sintesis karbohidrat yang berasal dari protein dan lemak (Khairuman dan Khairul, 2005).

Pada perlakuan P6 yang merupakan kombinasi pakan pelet dan cacing tubifex, memiliki kandungan protein sebanyak 38,97\%, lemak sebanyak 12,49\%, serat sebanyak 1,555\%, karbohidrat sebanyak 7,9765\% dan memiliki energi akhir sebesar 1886,045\% $\mathrm{kcal} / \mathrm{g}$. Adanya penambahan energi memberikan respon terhadap pertumbuhan yang berbeda dengan perlakuan pakan cacing tubifex (P3). Hal ini membuktikan bahwa adanya penambahan energi dapat meningkatkan pertumbuhan. Sumber energi yang paling mudah dan paling cepat dalam penyediaan energi apabila dibutuhkan adalah dari karbohidrat (Kusman, 2003). Almatsier (2002) berpendapat bahwa karbohidrat yang cukup akan mencegah penggunaan protein untuk sumber energi (sebagai penghemat energi). Bila kandungan karbohidrat dalam pakan tidak mencukupi, maka protein akan digunakan untuk memenuhi kebutuhan energi dengan mengalahkan fungsi utamanya sebagai zat pembangun. Faktor yang mempengaruhi kebutuhan energi pada ikan adalah spesies, aktifitas fisiologis, suhu, aliran air, ukuran tubuh, berat tubuh, umur, jumlah pakan. Adapun faktor lainnya adalah kepadatan ikan, kandungan oksigen terlarut, penumpukan feses dan sisa pakan, penanganan kurang baik dan penggunaan pakan kualitas rendah (Hariati, 1989).

Sesuai hasil penelitian Wilson dalam Stickney dan Novell (1997); bahwa pakan dengan kandungan kabohidrat sebanyak 2,5$10 \%$ dari berat pakan menghasilkan peningkatan pertambahan berat yang nyata namun bila kandungan karbohidrat ditingkatkan 
menjadi $15-20 \%$ dari berat pakan maka pertambahan berat akan menurun. Para ahli pakan menganjurkan untuk mengkombinasi pakan alami dengan pakan buatan agar tercipta keseimbangan asam amino di dalam tubuh benih ikan betutu (Afrianto dan Liviawaty, 2005).

Pada perlakuan P8 yang merupakan kombinasi pakan kerang darah dan cacing tubifex, kombinasi pakan tersebut memiliki kandungan protein sebanyak 51,255\%, lemak sebanyak $15,735 \%$, serat sebanyak $0,575 \%$, karbohidrat sebanyak $7,9675 \%$ dan memiliki energi akhir sebesar $804,12 \% \mathrm{kcal} / \mathrm{g}$. Perlakuan P8 ini mengandung protein yang tinggi dalam pakan tetapi pertumbuhan, laju pertumbuhan, laju pertumbuhan spesifik dan pertumbuhan panjang tubuh mutlak yang dihasilkan masih rendah dibanding dengan perlakuan P6.

Ketiga perlakuan tersebut (P6, P3, P8) memiliki kandungan protein tinggi di atas kebutuhan benih ikan pada umumnya termasuk benih ikan betutu. Menurut Cowey dan Walton dalam Halver (1989) bahwa protein yang berlebih dalam pakan akan dibuang melalui amoniak, glucosa, lemak, $\mathrm{CO}_{2}$, dan disimpan dalam bentuk ATP. Perbedaan perlakuan P8 (kombinasi pakan kerang darah dan cacing tubifex) dibanding dengan perlakuan P3 (pakan cacing tubifex) dan P6 (kombinasi pakan pelet dan cacing tubifex) terletak pada selisih jumlah energi dan menunjukkan adanya perbedaan pada pertumbuhan.

\section{Kesimpulan}

Pemberian pakan alami dan pakan buatan berpengaruh terhadap pertumbuhan benih ikan betutu (Oxyeleotris marmorata Bleeker). Jenis pakan yang berpengaruh terhadap pertumbuhan optimal benih ikan betutu (Oxyeleotris marmorata Bleeker) adalah kombinasi nutrisi pakan $50 \%$ pelet dan $50 \%$ cacing tubifex, dengan pertumbuhan sebesar $2,88467 \%$ berat tubuh/hari yang memiliki kandungan nutrisi pakan protein kasar = $38,97 \%$, lemak kasar $=12,49 \%$, serat kasar $=$ $1,555 \%$ dan karbohidrat $=7,9765 \%$ serta memiliki energi akhir $=1886,045 \% \mathrm{kcal} / \mathrm{g}$.

Selanjutnya diperlukan penelitian lebih lanjut pemberian berbagai jenis pakan pelet dengan atraktan berbeda, pemberian pakan dengan kombinasi nutrisi dari cacing tubifex, penelitian untuk mengetahui pertumbuhan benih ikan betutu skala masal di kolam, serta pengaruh cahaya terhadap aktifitas pakan dan pertumbuhan benih ikan betutu.

\section{Daftar Pustaka}

Afrianto, E dan E. Liviawaty. Pakan Ikan. Penerbit Kanisius. Yogyakarta. Hal 26-65

Ahmad, M. 1999. Makanan Ikan. Jakarta. Penerbit Swadaya Anggota IKAPI. Hal 101

Alhusin, S. 2002. Aplikasi Statistik dengan SPPS. 10 for Windows. $\mathrm{J}$ dan $\mathrm{J}$ Leaning. Yogyakarta. Hal 123-133

Almatsier, S. 2005. Prinsip Dasar Ilmu Gizi. Gramedia Pustaka Utama. Jakarta. Hal 132-155

Black, Kenneth D. dan A. D. Pickering. 1998. Biology of Farmed Fish. CRC Press. USA. $\mathrm{p}$

Buwono. 2000. Kebutuhan Asam Amino Essensial dalam Ransum Pakan Ikan. Kanisius. Yogyakarta. Hal 24-39

Effendie, M.I. 1997. Biologi Perikanan. Yayasan Pustaka Nusatama. Yogyakarta. Hal 73-78:92-100

Elliot, J. M and M. A. Hurley. 1995. Functional Ecologi. Volume IX. British Ecological Society. British. p. 625-627

Fitriani, A. 2002. Peran Pakan Alami (Daphnia $s p$ dan Tubifex sp) terhadap SR (Kelangsungan Hidup) dan pertumbuhan larva Ikan Baung (Mystis nemurus) di Balai Budidaya Air Tawar Sukabumi. Jawa Barat. Tugas Akhir. Budidaya Perairan Fakultas Kedokteran Hewan. Universitas Airlangga. Hal 4-8:30-33

Hadie, W dan Hadie, L. 2002. Udang Galah GI Marco. Penebar Swadaya. Jakarta.

Halver, J.E. 1972. Fish Nutrition. Academic Press. Inc. $713 \mathrm{p}$

Hariati, A.M. Maret 1989. Pakan Ikan NUFFIC/UNIBRAW/LUW/FISH

Fisheries Project. Universitas Brawijaya. Malang. Hal 1-13

Iskandar. 2003. Budidaya Lobster Air Tawar. Agromedia Pustaka. Jakarta.

Khairuman dan K. Amri. 2003. Membuat Pakan Ikan Konsumsi. Agromedia Pustaka. Jakarta. Hal 17

Khofifah, B. 2003. Pemberian Pakan Buatan (Fripak dan Flake) terhadap tingkat Kelulusan Hidup dan Pertumbuhan Larva Udang Galah (Macrobrachium rosenbergii de Man) di Balai Besar Pengembangan Budidaya Air Payau Jepara Jawa Tengah. Tugas Akhir. D3 Budidaya Peraiaran. Fakultas Kedokteran Hewan. Universitas Airlangga. Hal 48-50 
Komarudin, U. 2000. Betutu. Penebar Swadaya. Jakarta. Hal 1-13

Kurniawan. F. 2007. Pengaruh Pemberian Jenis Pakan Berbeda Terhadap Pertumbuhan dan Sintasan Ikan Black Ghost (Apteronotus Abifrons). Skripsi. Perikanan. Fakultas Peternakan dan Perikanan. Universitas Muhammadiyah. Malang. Hal 6-15 